\title{
アルミニウム合金ダイカスト内の鋳巣輪郭線に対する定量的評価
}

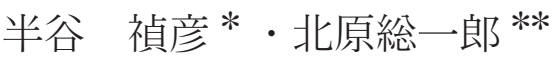

Journal of Japan Institute of Light Metals, Vol. 58, No. 12 (2008), pp. 639-643

\section{Quantitative evaluation of perimeter of porosity in aluminum alloy die casting}

\author{
Yoshihiko HANGAI* and Soichiro KITAHARA**
}

\begin{abstract}
Pore formation in high-pressure die casting is inevitable and pores adversely affect the mechanical properties and pressure tightness. Pores are induced by solidification shrinkage or entrapment of gas. To eliminate pores in die castings in the foundry floor, accurate identification of predominant cause of pores is essential. In this paper, the unbiased quantitative evaluation is proposed so that die casters can take corrective action to reduce pores. We proposed fractal dimension of shape and spatial distribution of porosity perimeter as the quantitative indicator of the identification of pores, namely, shrinkage or gas entrapment. The purpose of the present investigation is to demonstrate the validity of the proposed fractal dimensions by comparing the pores in different regions of die castings, which vary widely in porosity distribution. The proposed fractal dimensions are clearly different from inner region (shrinkage and gas induced pores are mixed) and surface region (only gas induced pores exist) in the die castings.
\end{abstract}

(Received March 27, 2008 Accepted July 16, 2008)

Keywords: die casting, aluminum alloy, quantitative discrimination, fractal analysis, porosity

\section{1. 緒言}

アルミニウム合金ダイカストは薄肉で複雑形状の製品を安 価に製造できることから，自動車部品製造になくてはならな

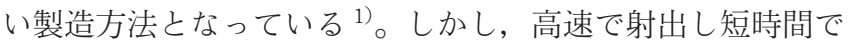
凝固するため, 製品内部における空洞欠陥（鋳巣）の発生を 避けることは困難である ${ }^{1), 2)}$ 。鋳巣は製品の機械的性質の低

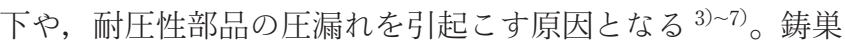

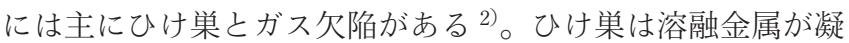
固収縮する際に，溶融金属補給経路が凝固し遮断されること により，新たな溶融金属の補給が閉ざされるために発生 する ${ }^{8)}$ 。ガス欠陥は溶融金属を金型内に射出する際に，金型 内の空気を巻込むことや，金型に塗布した離型剂が溶融金属 に接することで気化し溶融金属中に残留することなどにより 生じる ${ }^{8)}$ 。ひけ巣とガス欠陷は，その形状や製品内部での分 布状態など形態的な特徵が大きく異なり, 鋳巣の発生原因之 鋳巣の形態には何らかの相関があると考えられる。現状では 鋳巣不良が発生した場合，それらの形状を観察しながら見た 目の判断により鋳巣低減対策を採っている。しかし，実際に はひけ巣とガス欠陥は複合して発生し, 複合的な形態をして いることが多く2),9), 鋳巣をひけ巣とガス欠陷に明確に分別 することは困難である。そのため, 判断を誤り逆の対策を採 用してしまうことも多々あり, 鋳巣低減対策は困難な問題で

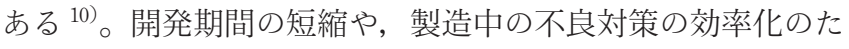
めには最適鋳造条件の求解を迅速かつ容易に行うことが重要 である。これに対する 1 つの方策として, 鋳巣の形態的特徵 を定量化することで, 鋳巣発生原因を定量的に評価すること
が考えられる。

鋳巣の定量化之鋳巣発生原因の関係に関する研究はいくつ か試みられており, 鋳巣の輪郭線形状を用いるもの 11) 15), 鋳巣間の第一近接間距離を用いるもの ${ }^{16)}$, 鋳巣面積の空間分 布を用いるもの 17),18) などが挙げられる。輪郭線形状を用い るあのは 1 つ 1 つの鋳巣を対象とした評価であるのに対し, 第一近接間距離や面積を用いるものは多数の鋳巣が空間上に 分布する状態（以後, “空間分布” と称する）を評価するも のである。

本研究は輪郭線形状について, 偏りが少なく, 空間分布の 特徵も取入れることが可能な定量的評価手法の構築を試み る。一般にひけの要因の強い鋳巣は複雑な輪郭線形状を有 し, ガスの要因の強い鋳巣は比較的滑らかな輪郭線形状を有 すると言われており ${ }^{8)}$, 輪郭線形状を定量化する方法はその ことに着目したものである。この手法は輪郭線形状を正確に 抽出する必要があるため, X 線 CT など低解像度の鋳巣画像 しか得られない観察方法への適用は困難であり, 光学顕微鏡 観察など高解像度の鋳巣画像が必要であるが，その分精度の よい定量的評価ができることが期待される。

現在までの研究では, 1 つの鋳巣に着目しその輪郭線形状 に対して定量化を行っていたため, 空間分布の特徵を評価す ることができなかった。例えば, Fig. 1 (a) はダイカストに 発生した鋳巣の光学顕微鏡画像であり, Fig. 1（b）は 2.1 節で 後述するように鋳巣とアルミニゥム合金を二值化により分離 し, 鋳巣の輪郭線を強調した画像である。矢印の鋳巣の輪郭 線の定量化には Fig. 1 (c) のように周囲の鋳巣を除去するた め，隣接した鋳巣との関係の評価が久落していた。また個々

*群馬大学大学院工学研究科機械システム工学専攻（† 376-8515 群馬県桐生市天神町 1-5-1)。Department of Mechanical System Engineering, Graduate School of Engineering, Gunma University (1-5-1, Tenjin-cho, Kiryu-shi, Gunma 376-8515).

**グンダイ(森（伊勢崎市)。Gundai Co., Ltd. (Isesaki-shi, Gunma). 

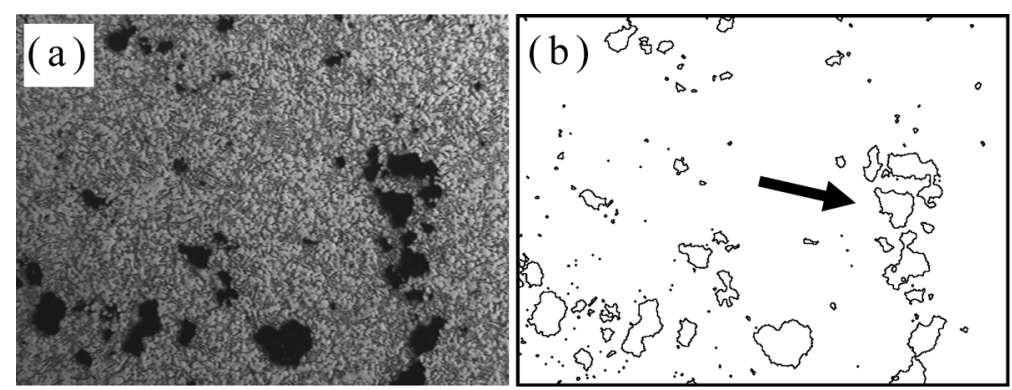

(c)

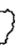

$200 \mu \mathrm{m}$

Fig. 1 Schematic illustration of fractal analysis method of earlier study. (a) Micrograph image of the pores in die casting. (b) Binarized and emphasized image of the perimeter of pores. (c) Extraction of the target porosity.

の鋳巣を対象とするため, 観察しやすい鋳巣を抽出してしま うといった任意性が生じ偏った評価になる可能性があること が問題であった。

そこで本研究では, Fig. 1（b）のような画像上に存在する すべての鋳巣の輪郭線に対してフラクタル解析 ${ }^{19)}$ 21) を行う ことにより，空間的な分布の特徵も考慮でき，かつ偏りの少 ない定量的評価を試みる。フラクタルは, 図形の一部分を拡 大しても同じ図形が繰返される自己相似性という大きな特徵 を持っている。このような性質を持つものは自然界の中に数 多く見られ, 海岸線や雲の輪郭線 ${ }^{19)}$, 宇宙の質量分布 ${ }^{20)}$, 腫瘍細胞の輪郭線形状や細胞核の空間分布 ${ }^{22)}$ などに対して フラクタル性が確認されている。ダイカスト内部に発生する 鋳巣輪郭線の形状や空間分布においても, 同様にフラクタル 性を持つものと期待される。自己相似性という特徽を有すれ ば，顕微鏡などの倍率によらない評価が可能となる。またフ ラクタルは, フラクタル性を有する形態の複雑性をフラクタ ル次元により定量化できるという特徵も有している。フラク タル解析により鋳巣発生原因の異なる鋳巣を定量的に評価で きるむのと期待される。すでに 1 つの鋳巣の輪郭線形状 12) 15) や鋳巣面積の空間分布 ${ }^{17), 18)}$ がフラクタル性を有し，フラク タル次元により定量的な評価が可能であることが示されてい る。それらの評価間の相関関係の有無や物理的な意味は不明 であるが，すべて鋳巣形態の特徵を表す量として鋳巣の定量 的評価に有効であると考えられ, 今後更なる調査検討が必要 である。

本研究では, まず画像全体に存在するすべての鋳巣輪郭線 を対象としたフラクタル解析手法を構築する。次にダイカス 卜製品の表層部（主にガス欠陥が観察される領域）に発生し た鋳巣と内層部（ガス欠陷とひけ巣が混在して観察される領 域）に発生した鋳巣を，本手法により定量的に評価を行う。 関心領域全体における鋳巣輪郭線の形状や空間分布といった 鋳巣形態の特徵を定量的に評価可能であるか検討する。

\section{2. 実験方法}

\section{1 鋳巣観察方法}

鋳巣観察は, Fig. 2 に示すような実際に自動車製品として 用いられているカーエアコン用コンプレッサの A 領域断面に ついて行った。製品はアルミニウム合金ダイカスト $\mathrm{ADC} 12^{23)}$ で大気開放ダイカストにより製造した。Fig. 2 中の A 領域は 鋳巣が多く観察され，後加工により鋳巣が露出し圧漏れが問 題となっている領域である。A 領域の製品表層部と製品内層

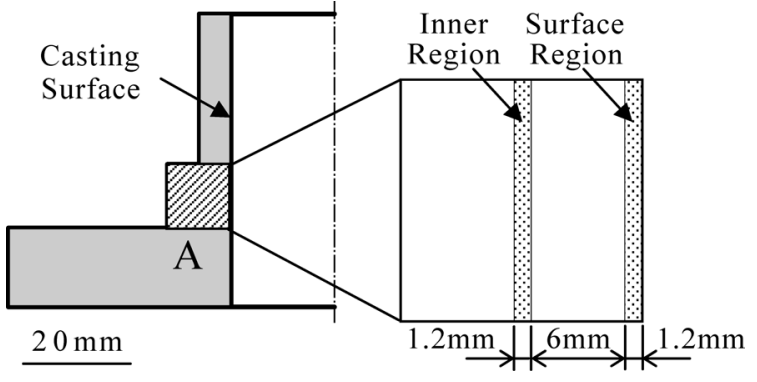

Fig. 2 Schematic illustration of the cross section of the housing of a car air conditioner compressor made by $\mathrm{ADC} 12$ die casting aluminum alloy, which is used in this investigation. Optical microscopy observation was carried out for the surface region and inner region of region $\mathrm{A}$.

部について顕微鏡観察を行った。まずカーエアコン用コンプ レッサ製品 3 個について，ほぼ同じ箇所から A 領域が入るよ うにファインカッターで切出し観察用試験片とした。次に観 察用試験片を樹脂埋めし, $\mathrm{SiC}$ 耐水研磨紙 \#2400 までの粗研 磨, およびアルミナ $1 \mu \mathrm{m}$ の精研磨後, 画像を光学顕微鏡に 取付けた CCD カメラでパソコンに取込んだ。Fig. 3 に画像例 を示す。Fig. 3 (a) は内層部, Fig. 3（b）は表層部のものであ る。灰色と白色の混在する部分がアルミニウム合金, 黒色の 部分が鋳巣である。取込んだ画像の大きさは約 $1.2 \mathrm{~mm} \times$ $0.9 \mathrm{~mm}$, ピクセル数は 640 ピクセル $\times 480$ ピクセルである。次 に取込んだ画像に対して二值化処理を施した。この際, アル ミニウム合金を白, 鋳巣を黒と分離するような閾值を適用す ることで，鋳巣のみの画像を作成することができる。その後， 鋳巣の輪郭線を検出した。Fig. 3 (a)，（b）で示した画像は, それぞれ Fig. 3 (c), （d）のようになる。最後に得られた鋳巣 輪郭線画像に対して, ボックスカウンティング法 ${ }^{20,21)} に よ$ るフラクタル解析を行い, フラクタル次元 $D_{\mathrm{p}}$ を算出した。 1 製品の表層部，内層部それぞれの領域について 11 15 か所か ら画像を取込み, 表層部, 内層部それぞれ合計 39 画像, 35 画像について解析を行った。画像枚数が表層部の方が多いの は，表層部においては鋳巣が極端に少なくフラクタル解析が 行えない場合があることを考慮したためである。

\section{2 フラクタル解析方法 20$), 21$ )}

ボックスカウンティング法はコンピュータ処理によりフラ クタル解析を簡便に行うことが可能な手法の 1 つである。

Fig. 4 (a) に示す例のように, 鋳巣の輪郭線を検出した画像 に対して, 一辺が $d$ の正方形（ボックス）で画像全体を被覆 


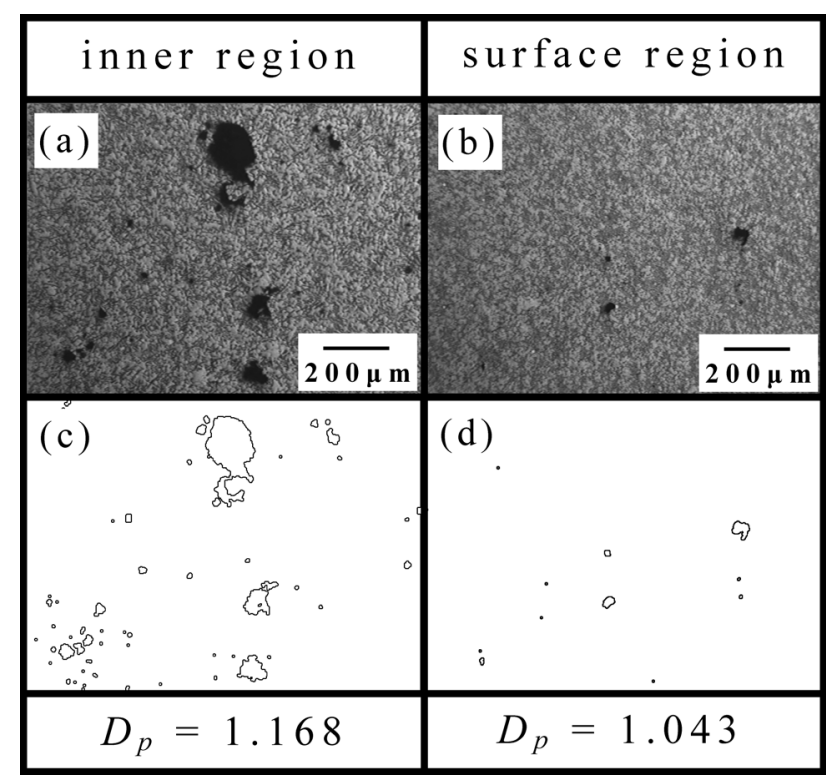

Fig. 3 Sample images of pores and their fractal dimension $D_{p}$. (a) Micrograph image of the inner region scanned by a CCD camera. (b) Micrograph image of the surface region scanned by a CCD camera. (c) Binarized image of pores of (a). (d) Binarized image of pores of (b).

し, 輪郭線を含むボックスの個数 $N(d)$ を求める。 $d$ を様々 に変化させて, Fig. 4 (b) に示すように $d$ を横軸, $N(d)$ を 縦軸にとり両対数でプロットする。このプロットしたものが おおよそ線形近似できればフラクタル性を有し，その傾きの 絶対值をフラクタル次元 $D_{p}$ とする。Fig. 4 の例においてもプ ロットしたものが線形近似できることから, 本研究で対象之 するような鋳巣輪郭線形状はフラクタル性を有していること がわかり，そのフラクタル次元は $D_{p}=1.406$ となる。

本研究では Fig. 5 に示すように, まず輪郭線を抽出した Fig. 3 (c)，（d）のような画像の一部を一辺が 128 ピクセルの 正方形で囲い, その正方形の内部に対して, ボックスの一辺 を 128，64，32，16，8，4，2，1 と変化させてボックスカウ ンティング法を適用する。次にこの一辺が 128 ピクセルの正 方形を縦と横それぞれ独立に 1 ピクセルずつ移動させ, 合計 (640-128)×(480-128) 汃所についてそれぞれ $D_{p}$ を算出する。 その中から 1 以上の $D_{p}$ すべてについての平均をとり，その 值を対象とする画像の $D_{p}$ とする。画像全体を一気にフラク タル解析せず，一辺が 128 ピクセルの正方形で被覆しそれを 移動させたのは，Fig. 6 (a) に示すように画像上にほとんど 鋳巣が表れない表層部において一辺が 256 ピクセルの正方形 で被覆した場合や正方形内で鋳巣に偏りがある場合, Fig. 6 （b）に示すように大きなボックスサイズ $d$ のところで $\log N$ (d) に0 が続き, フラクタル性が破られフラクタル次元を正 確に算出することができない場合があるためである。このよ うに鋳巣が疎に分布する場合には, 被覆する正方形の大きさ や, 被覆位置の調節が必要である。本研究では, 今までの経 験から 128 ピクセルの正方形で被覆することにし，その被覆 する正方形を 1 ピクセルごとに移動させてフラクタル解析を することで，フラクタル性を有し正確にフラクタル次元を算 出できるものを探索した。また，フラクタル次元が 1 以上の $D_{p}$ のみを採用したのは, Fig. 6 (b) に示すようにフラクタル 性が破られフラクタル解析がうまくいかない場合, $D_{p}$ が 1 以 (a)

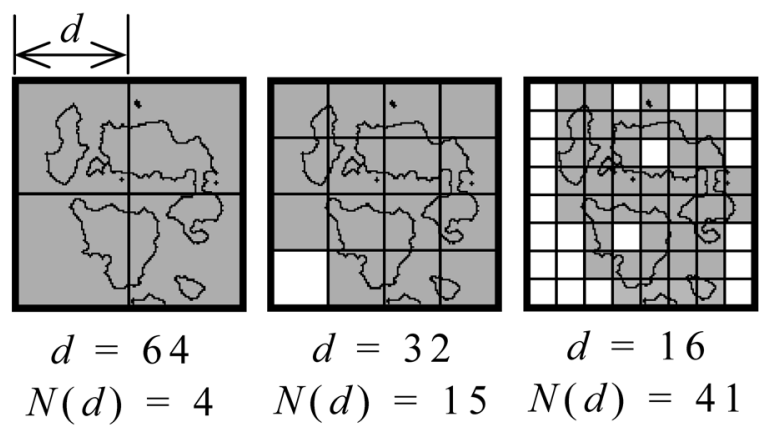

(b)

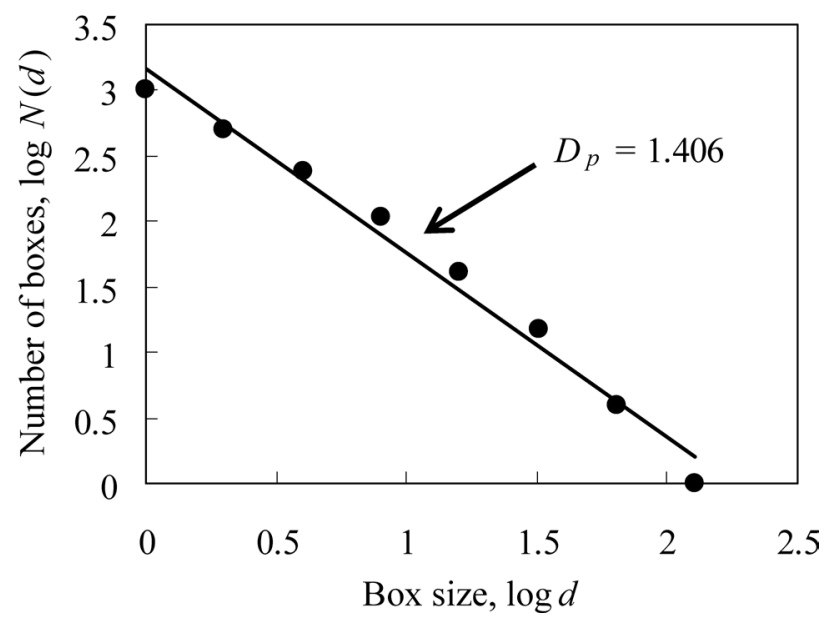

Fig. 4 Schematic illustration of box-counting method. (a) The shaded boxes are counted. (b) Relationship between box size $d$ and number of boxes $N(d)$. The absolute value of the gradient of linearly approximated curve gives the fractal dimension $D_{p}$.

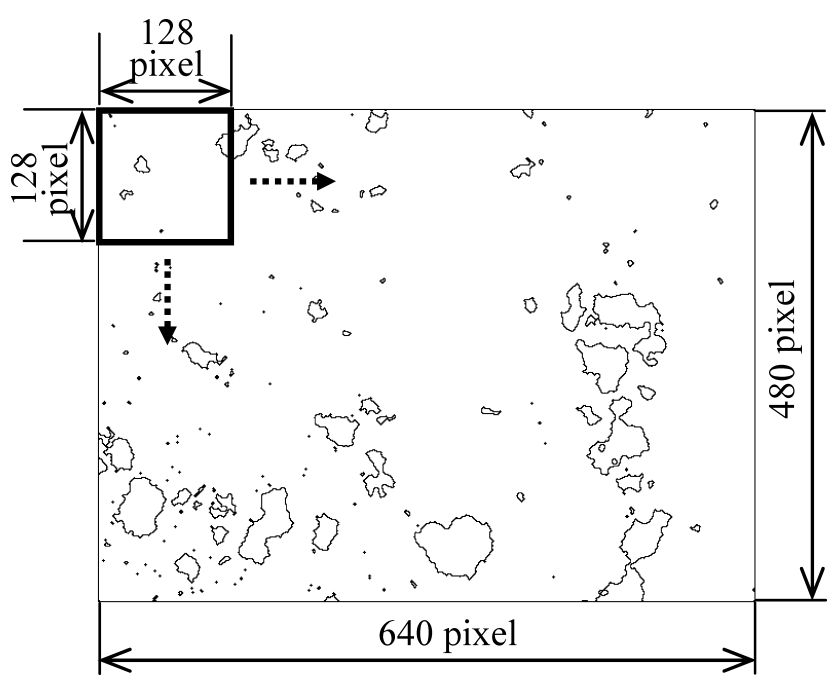

Fig. 5 Schematic illustration of calculating fractal dimension $D_{p}$ of targeted binarized and emphasized image of the perimeter of pores.

下となる場合が多いからである。直線の場合 $D_{p}=1$ であり, 鋳巣の輪郭線は単純な直線よりも複雑であることから妥当な 閾值であると考えられる。

ただし, 内層部についてはこのように鋳巣が疎になる部分 
(a)

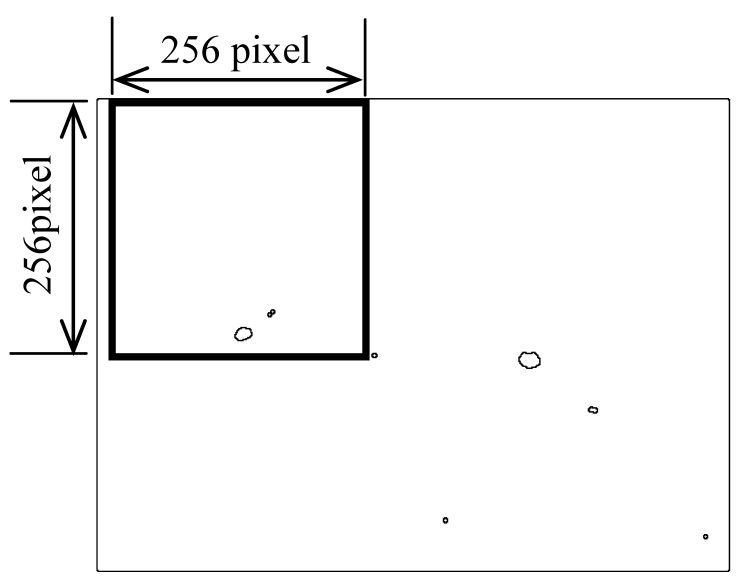

(b)

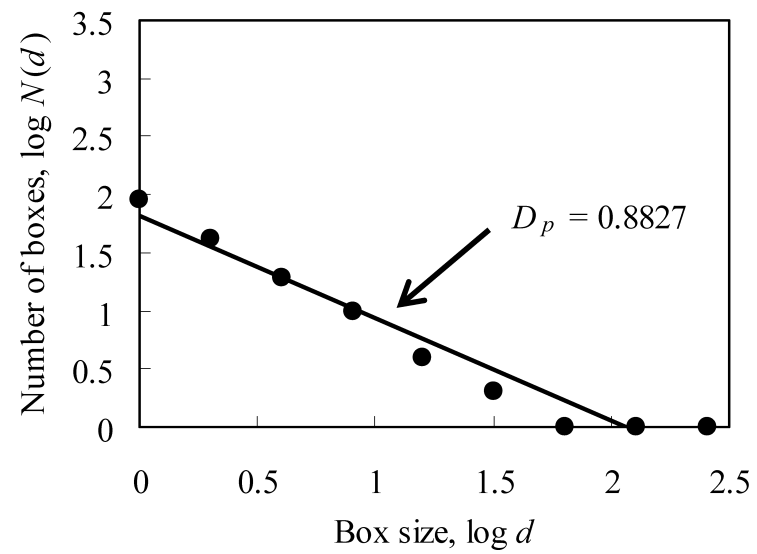

Fig. 6 Schematic illustration of fractal analysis which cannot calculate the fractal dimension $D_{p}$ precisely. (a) Binarized and emphasized image of the perimeter of pores which contains a small amount of pores. (b) Relationship between box size $d$ and number of boxes $N(d)$ of (a).

は非常に稀であり，どの領域を採ってもほぼ鋳巣が存在する ため，囲う正方形の大きさを大きくし移動させる必要がなく， 正確かつ簡便にフラクタル解析を行えるものと思わ机る。通 常，ダイカストメーカなぞで実際に使用する場合には，鋳巣 が多く発生した場合がターゲットになるため簡便に行うこと が可能であり，鋳巣画像さえあればコンピュー夕処理により すべて自動で，しかも計算時間はほとんどかからずに $D_{p} を$ 算出することができる。

\section{3. 実 験 結 果}

鋳巣輪郭線の形状が複雑であればあるほど，また鋳巣輪郭 線が観察断面に占める割合が高ければ高いほど，フラクタル 次元 $D_{p}$ は高い值を示す。例えば Fig. 3 の場合, 内層部は $D_{p}=1.168$, 表層部は $D_{p}=1.043$ となり, 一見して複雑な輪郭 線の形状や空間分布を示している内層部の方が高い $D_{p}$ を示 している。Fig. 7 に内層部，表層部それぞれにおける $D_{p}$ と その頻度を示す。内層部は 35 画像, 表層部は 31 画像につい てのものである。表層部については，鋳巣画像中の鋳巣が極 端に少なく $D_{b}$ が算出できないあのああり，それらを除いた あのである。表層部では $1<D_{p} \leqq 1.04$ にピークがあり， $80 \%$ 以

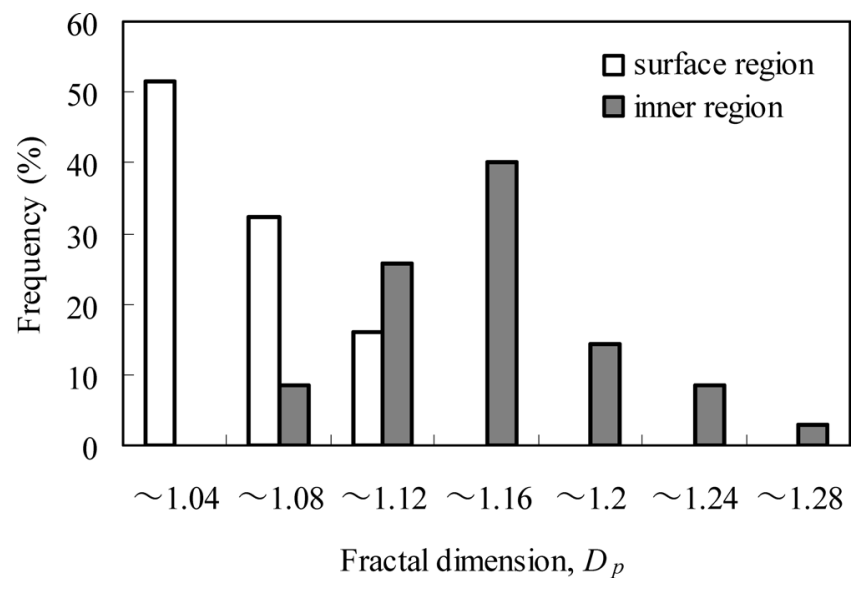

Fig. 7 Distribution of fractal dimension $D_{\phi}$ in surface region and inner region.
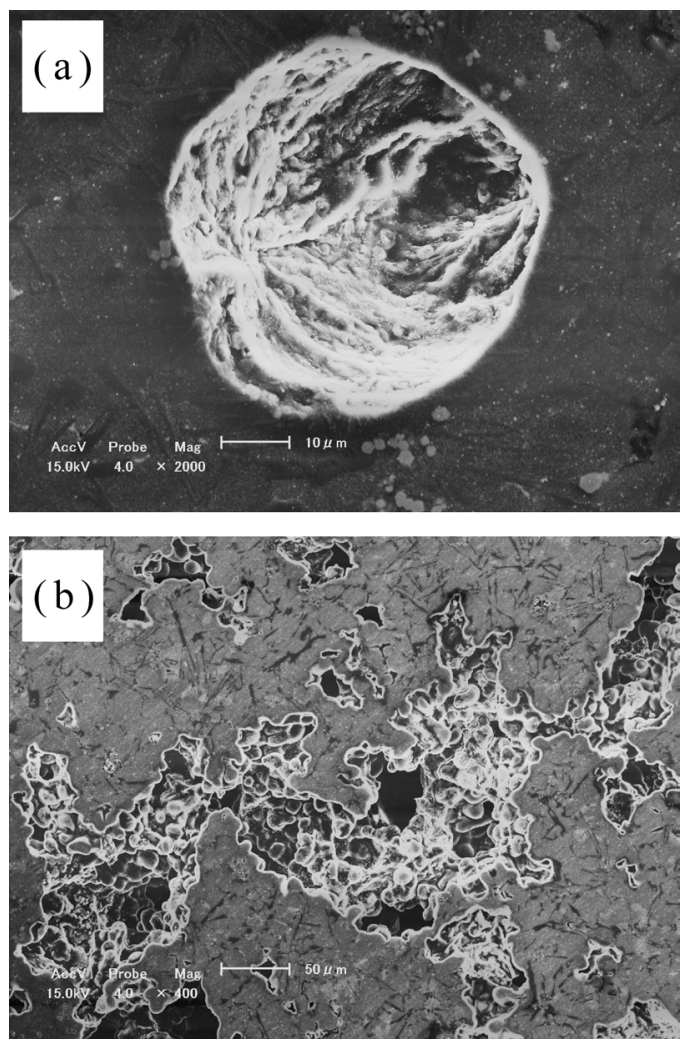

Fig. 8 SEM images of pores. (a) Pore in the surface region. (b) Pore in the inner region, in which dendrites clearly appear.

上の画像が $1<D_{p} \leqq 1.08$ の值を示した。そ机に対し, 内層部で は $1.12<D_{p} \leqq 1.16$ にピークがあり, 表層部に比べて広い範囲 に分布している。

現実のダイカスト製品においては，一般に溶融金属は金型 に接した部分から冷却凝固するため, 内層部は最後まで凝固 せずひけ巣が発生しやすい。一方ガス欠陥は夕゙イカスト全体 に分布している ${ }^{10)}$ 。そのため, 表層部ではひけの要因が少な くガスが主要因となる傾向にあり, 内層部ではひけの要因と ガスの要因が混在，あるいはひけが主要因となる傾向にある。 本研究で用いた試験片を対象に, SEM による観察結果を Fig. 8 に示す。表層部では Fig. 8 (a) に示すように, デンドライ 卜形状がほとんど観察されない鋳巣が主であり，しかも輪郭 
線形状は滑らかであった。一方, 内層部では Fig. 8 (b) に示 すように，鋳巣壁にデンドライトが存在する鋳巣が多く観察 され, しかも輪郭線形状は複雑で密集して存在していた。ま た，表層部で観察されたようなデンドライト形状がほとんど 観察されない鋳巣も存在した。これらのことを考慮すると, 表層部で低い $D_{p}$ を示し, 内層部で高い $D_{p}$ を示したのは, 現 実のダイカスト製品内の鋳巣の状況に対応しているものと考 えられる。また, 内層部では領域がわずかに変化しただけで ひけ巣の量が大きく変化するため, 内層部に拉いて $D_{p}$ が広 い範囲に分布しているものと考えられる。すなわち， $D_{p}$ はひ けの要因の強さを定量的に表現している屯のと考えられる。

一般に鋳巣の発生原因をガス由来か，ひけ由来か明確に識 別することは困難である。しかし， $D_{p}$ が高い值を示せば金型 温度の調節や湯口速度の増加, 鋳造圧力の増加などといった ひけ巣対策, $D_{p}$ が低い值を示せばガス抜きの位置や大きさの 変更, 鋳造圧力や射出速度の変更といったガス欠陥対策を文 献 ${ }^{8)}$ 10) などを参考にして迅速かつ正確に行えるものと思われ る。

\section{4. 結言}

本研究では, ダイカスト製品に発生した鋳巣の発生原因を 定量的に識別するために, 鋳巣の輪郭線の形状や空間分布に 対して，偏りの少ない定量的評価を試みた。以下に得られた 結果を示す。

(1) 鋳巣の光学顕微鏡画像上に存在するすべての鋳巣の輪 郭線を用いたフラクタル解析を行い, 鋳巣輪郭線の形状や空 間分布がフラクタル性を持つことがわかった。すなわち本提 案手法により, 特定の鋳巣の抽出による任意性を排除すると ともに, 鋳巣の空間分布を屯評価することが可能であること がわかった。

（2）ダイカストにおいて, ガスの要因が強い表層部とひけ の要因の強い内層部で, 明確なフラクタル次元の差が現れた。 すなわち, 鋳巣輪郭線の形状や空間分布のフラクタル解析に より, 関心領域全体における鋳巣形態の特徵を定量的に評価 することが可能となり，鋳巣対策の指針となる可能性がある ことが示された。
本研究の遂行に当たり, 東京大学生産技術研究所の吉川暢 宏教授, 福井大学大学院工学研究科 桑水流理准教授には有 益なご助言を賜った。ここに厚く感謝いたします。

\section{参考文献}

1）社団法人日本ダイカスト協会：ダイカストって何?-DIE CASTING一, 社団法人日本ダイカスト協会, (2003).

2) D. F. Allsop and D. Kennedy: Pressure Diecasting, Part 2: The Technology of the Casting and the Die, Pergamon Press, Ltd., (1983), pp. 6-7.

3) E. J. Vinarcik: High Integrity Die Casting Process, John Wiley \& Sons, (2003).

4) M. Avalle, G. Belingardi, M. P. Cavatorta and R. Doglione: International Journal of Fatigue, 24 (2002), 1-9.

5) S. G. Lee, G. R. Patel, A. M. Gokhale, A. Sreeranganathan and M. F. Horstemeyer: Scripta Materialia, 53 (2005), 851-856.

6) J. Linder, A. Arvidsson and J. Kron: Fatigue \& Fracture of Engineering Materials \& Structures, 29 (2006), 357-363.

7) P. T. E. Gebhard: Die Casting Engineer, 47 (2003), 54-56.

8）社団法人日本鋳造工学会ダイカスト研究部会：ダイカストの鋳 造欠陥・不良及び対策事例集, 社団法人日本鋳造工学会, (2000).

9) S. G. Lee and A. M. Gokhale: Scripta Materialia, 55 (2006), 387-390.

10) D. L. Cocks: Die Casting Engineer, 33 (1989), 26-28.

11）西 直美, 駒崎 徹：鋳物講演大会講演概要集, 125 (1994), 6.

12) Bo-Tao Lee, Shu-Zu Lu and A. Hellawell: TMS Annual Meeting, Cast Shop Technology, (1997).

13) P. Hairy: Fonderie Fondeur Aujour'hui, 265 (2007), 12-25.

14）半谷禎彦, 吉田俊介, 北原総一郎, 天田重庚：日本金属学会誌, 70 (2006), 568-571.

15) Y. Hangai and S. Kitahara: Mater Trans., 49 (2008), 782-786.

16) A. Tewari, M. Dighe and A. M. Gokhale: Materials Characterization, 40 (1998), 119-132.

17）半谷禎彦, 北原総一郎：日本金属学会誌，71 (2007), 688-692.

18）半谷禎彦, 北原総一郎, 桑水流理, 吉川暢宏 : 鋳造工学, 80 (2008), 284-289.

19) Mandelbrot Benoit: The Fractal Geometry of Nature, W H Freeman \& Co., (1982).

20）高安秀樹：フラクタル，朝倉書店，(1986).

21）松下 貢：フラクタルの物理（I）基礎編, 裳華房, (2002).

22) 高安秀樹, 佐藤 隆, 横山俊朗 : MEDICAL IMAGING TECHNOLOGY, 15 (1997), 587-591.

23） JIS 規格：JIS H 5302，財団法人日本規格協会，（2006）. 